\title{
Phytochemical Composition of an Underutilized Plant Sorrel/Roselle (Hibiscus Sabdariffa L.) Cultivated in India
}

\author{
Ghazala Riaz $^{1(\mathbb{D})}$, Satya Narayan Naik ${ }^{2(\mathbb{D})}$, Meenakshi Garg ${ }^{3(\mathbb{D})}$, Rajni Chopra ${ }^{4, *}$ \\ 1 Department of Food \& Nutrition, Institute of Home Economics, University of Delhi, F-4, Hauz Khas Enclave, New \\ Delhi-110016. India \\ 2 Centre for Rural Development \& Technology, Indian Institute of Technology Delhi, Hauz Khas, New Delhi-110016 \\ 3 Department of Food Technology, Bhaskaracharya College of Applied Science, University of Delhi. India \\ 4 Department of Food Science and Technology, National, Institute of Food Technology Entrepreneurship and Management. \\ Sonipat, Haryana-131028, India \\ * Correspondence: rajnichopra.niftem@gmail.com;
}

Received: 20.09.2020; Revised: 18.10.2020; Accepted: 19.10.2020; Published: 21.10.2020

\begin{abstract}
Roselle (Hibiscus sabdariffa L) belongs to the Malvaceae family is a multipurpose plant with high economic importance and worldwide fame for its nutritional and therapeutic value, but unfortunately, it is underutilized in India. Their calyces are utilized as ethnic food and in traditional medicine to cure many degenerative diseases in different parts of the world and by the tribal of India. However, no evidence is available in the literature regarding the existent quality assessment of the roselle calyces in India. Therefore, the objective of the study was to characterize the calyces of roselle (Hibiscus sabdariffa L.) from India. The calyces were grounded, sieved to 20 mesh sizes, and stored in the refrigerator for further analysis. The parameters analyzed included nutritional composition and the biologically effective component that is total phenols and the total anthocyanins. A procedure to measure the anthocyanins by $\mathrm{pH}$-differential UV-visible spectrometry was followed. Total phenolic content was assessed by the Folin Ciocalteau method, and gallic acid was used as a standard. The individual anthocyanins present in Hibiscus were characterized by TLC. The results reveal that these indigenous powdered calyces are rich sources of macro and micronutrients, bioactive components like polyphenols and flavonoids, especially anthocyanins. Our study substantiates the health /nutritional claims and validates its applicability in functional food processing and therapeutic treatments.
\end{abstract}

Keywords: Hibiscus sabdariffa; nutritional component; anthocyanins; total phenols.

(C) 2020 by the authors. This article is an open-access article distributed under the terms and conditions of the Creative Commons Attribution (CC BY) license (https://creativecommons.org/licenses/by/4.0/).

\section{Introduction}

Roselle (Hibiscus sabdariffa L.) is a multipurpose plant, is a member of the Malvaceae family, and is anticipated as a medicinal plant. It is widely distributed in tropical and subtropical regions and originally native to Africa. It is known by various vernacular names in different countries, roselle, karkade, zobo, bissap, congo, etc.; however, the most common among them is roselle. Usually, the plant is cultivated for its stem, leaves, and calyces. The stems are primarily used for the production of fiber, which can be used as a substitute for jute in making burlap. Nevertheless, the economic interest of roselle exists in the dried calyces, which are perhaps a good resource of carbohydrate, dietary fiber, vitamins, minerals, and bioactive compounds such as organic acids, phytosterols, and polyphenols [1]. The phenol content in the plant consists primarily of anthocyanins like delphinidin-3-sambubioside and cyanidin- 3- sambubioside, delphinidin -3-glucoside, and cyanidine-3-glucoside [3-4], which 
contribute to their antioxidant properties 5]. Roselle calyces are often used in the production of beverages such as herbal tea, wine, and preserves like syrup, jams, jellies, and sauces 6]. They are used as a natural colorant and flavoring agent in ice cream, cake, pudding, and rum 7-8]. Its brilliant red color and distinctive flavor make it a cherished food product. The juice from the calyces of roselle is presumed to be a health-augmenting drink and is generally expended dietary items in certain parts of the globe.

Furthermore, roselle has certain therapeutic properties; the reported health benefits of consuming the herbal tea involves the hypotensive effect, hypolipidemic effect, diuretic, antimicrobial, anti-carcinogenic, remedy for relieving coughs and biliousness [1,7,9-13], toothaches, urinary tract infections [14], improves the kidney functions [15] and is neuroprotective [12] These research reports highlighting the health improvements linked with the consumption of roselle acquired products has attracted many researcher and scientist to characterize the components of the calyces.

Surprisingly no fundamental research in terms of the nutritional and biological composition of the calyces has been carried out in India. So, the objective of our study was to investigate the nutritional and bioactive component of the locally produced Indian sorrel/roselle that will validate its applicability in functional food processing.

\section{Materials and Methods}

\subsection{Raw material.}

The present study was carried out at the Department of Food and nutrition, institute of home economics, university of Delhi. Dried roselle calyces were procured from Maharashtra. They were carefully cleaned, freed from foreign material, and were grounded using the kitchen mixer grinder, then sieved to 20 mesh sizes and stored in the refrigerator in an airtight container for further analysis.

\subsection{Chemicals.}

All the solvents and chemicals were of analytical grade. High-performance liquid chromatography (HPLC) grade solvents, ethanol, methanol, all the standards, gallic acid, Folin Ciocalteu's phenol reagent, and anhydrous sodium carbonate were purchased from Sigma Aldrich.

\subsection{Analytical methods.}

2.3.1 Nutritional composition of dried Indian sorrel/roselle (Hibiscus sabdariffa L.) calyces.

\subsubsection{Proximate composition.}

Proximate composition of dried roselle calyces that included moisture percentage, fat, protein, carbohydrate, ash, and dietary fiber was done using AOAC methods (2006). The total carbohydrate was calculated by the difference method.

\subsubsection{Vitamins composition.}

Dried powdered calyces were supplied to Arbro India Private Limited, Delhi, for analysis of Ascorbic acid (vitamin C) and vitamins (B1, B2, B3, B5, B6, B9, and B12). The protocol followed for vitamin $\mathrm{C}$ was done through high-performance liquid chromatography 
as per APL/CHE/STP-173. Vitamins B1, B2, B3, B5, B6, B9, and B12 were analyzed following the protocol APL/CHE/STP-012, APL/MIB/STP-036, APL/MBI/STP-006, and APL/MBI/STP-006, respectively.

\subsubsection{Mineral composition.}

Sample ash in $\mathrm{HCl}$ was used to analyze the mineral contents ( $\mathrm{Ca}, \mathrm{Mg}, \mathrm{K}, \mathrm{Fe}$, and $\mathrm{Na}$ ) as per AOAC (2005) using Atomic Absorption Spectrophotometer, Perkin-Elmer Model (AANALYST 2000). (Cu, Mn, and Zn) were analyzed using the technique inductively coupled plasma technique mass spectrometry (ICP-MS) according to the method described by [16] with slight modification.

\subsubsection{Sugar profile.}

The sugar profile of dried roselle calyces was analyzed following the method of [17] with slight modification. PerkinElmer HPLC, with a refractive index detector (Shodex RI 71) system consisting of a series of 200 Micropump, was used for the analysis. Appropriately diluted standards and samples were centrifuged and filtered through a Millipore filter before analysis. The column used was kromacil amino column $(250 \mathrm{~mm} \times 4.6 \mathrm{~mm}$ with $5 \mu \mathrm{m}$ particle size) at $35^{\circ} \mathrm{C}$ was used for analysis. The mixture of acetonitrile and distilled water (80: 20, $\mathrm{vol} / \mathrm{vol}$ ) was used as an eluent, and the flow rate kept $1 \mathrm{ml} / \mathrm{min}$. The injection volume was 20 $\mu \mathrm{L}$. Calibration standards were fructose, glucose, and sucrose.

\subsubsection{Organic acid composition.}

Organic acids were determined by high-performance liquid chromatography using an absorbance detector according to the method described by Dias et al. [18]. The column used was C18. Oxalic acid, malic acid, and fumaric acid were used as standards. The findings were stated as percentage dry weight basis.

2.3.2. Bioactive composition of dried Indian sorrel/roselle (Hibiscus sabdariffa L.) calyces.

\subsubsection{Total phenolic content.}

Total phenols present in the calyces powder were ascertained using the FolinCiocalteau method [19] with a slight modification. Different concentrations of gallic acid were used to draw the standard graph, and total phenol present in the sample was expressed as $\mathrm{mg}$ $\mathrm{GAE} / \mathrm{g}$.

\subsubsection{Total anthocyanins content.}

Total anthocyanins content was examined as per the method described by [20]. $50 \mathrm{~g}$ of dried calyces was extracted thrice with $100 \mathrm{ml}$ of acidified methanol, macerated for 1 hour, and filtered through Whatman no.1 filter paper; the filtrates were combined together and concentrated at $40^{\circ} \mathrm{C}$ under vacuum in a rotary vacuum evaporator (5037- "JAISBO'). The samples were then analyzed for total anthocyanin content using PerkinElmer LAMBDA 25 UV-VIS spectrophotometer. 
2.3.2.3. Identification of anthocyanins by thin layer chromatography (TLC).

The anthocyanin extracts were prepared by dissolving $1 \mathrm{~g}$ of powdered indigenous calyces to $6 \mathrm{ml}$ of the solvent containing methanol and $25 \% \mathrm{HCl}$ in the ratio of 9:1 with continuous for 15 minutes and then filtered through Whatman no 1 filter paper. $25 \mu 1$ of the filtrate was used for TLC investigation. The adsorbent used was $0.2 \mathrm{~mm}$ Merck silica gel 60 $\mathrm{F}_{234}$ precoated TLC plates, and the plates were developed using n-butanol-glacial acetic acidwater 40:10:20 [21, 24].

\section{Results and Discussion}

\subsection{Nutritional composition of dried Indian sorrel/roselle (Hibiscus sabdariffa L.) calyces.}

\subsubsection{Proximate composition.}

The results of the proximate composition of dried Indian sorrel/roselle (Hibiscus sabdariffa $\mathrm{L})$ calyces are presented in Table 1 . The results are a mean of three replication $(\mathrm{n}=3)$. , The moisture content of the dried roselle calyces powder was found to be $9.84 \%$, which was almost similar to the value in the variety from the northeast region of India, with the moisture content of $9.53 \%$ as reported by [22]. The dietary fiber in our sample was $35.22 \pm 0.2 \%$, which is slightly greater than that reported (33.9\%) in a study by [23]. $40 \mathrm{~g}$ of dietary fiber in the daily adult diet is recommended (FAO/WHO, 1998). The dietary fiber helps in lowering the blood glucose level and effective against hyperlipidemia.

However, there are minor differences in the concentration of other macronutrients in the variety from the northeast region of India and the western part of India, although the trend is the same that is carbohydrates being the maximum macronutrients followed by dietary fiber, protein, total ash, and fat. The proximate composition of Hibiscus sabdariffa L. was reviewed by [1,2], highlighting the carbohydrate to be the highest macronutrients present in roselle calyces. In their review, they had pointed out that the differences in the concentration of several macronutrients, as shown in different studies, were primarily due to environmental factors.

Table 1. Proximate composition of dried Indian sorrel/roselle (Hibiscus sabdariffa L.) calyces. (\% dry weight basis).

\begin{tabular}{l|l} 
Test & Result \\
\hline Moisture & $9.84 \pm 0.01$ \\
\hline Total ash & $4.5 \pm 0.02$ \\
\hline Fat & $0.50 \pm 0.03$ \\
\hline Protein & $5.82 \pm 0.03$ \\
\hline Carbohydrate & $5.82 \pm 0.03$ \\
\hline Total dietary fiber & $35.22 \pm 0.2$
\end{tabular}

Results are expressed as a mean \pm standard deviation of three measurements.

\subsubsection{Vitamin composition.}

Indian sorrel was analyzed for its vitamin B and C (ascorbic acid) by HPLC (Table 3). Vitamin A was not detected in the sample, but vitamin C content was $(12.20 \mathrm{mg} / 100 \mathrm{~g})$ dry weight sample. Figure 2 shows the distinct peak of vitamin $\mathrm{C}$ (ascorbic acid) in the HPLC chromatogram. The results are coherent with the fact that calyces are rich in ascorbic acid, although this value was lower as compared to the earlier study by Wong et al. [24 ] and AbouArab et al. [25 ] and higher than that reported by Luvonga, [26]. This difference in the value may be attributed to the source of calyces. Ascorbic acid is good for health and prevention of 
diseases in which free radicals are involved as it acts as an antioxidant. It helps in the absorption of dietary iron, involved in collagen synthesis and formation of bone teeth calcification.

Niacin (B3) was the most abundant vitamin $(1484.3 \mathrm{mg} / 100 \mathrm{~g})$, followed by pyridoxine, folic acid, riboflavin, and pantothenic acid. Thus, the dried Indian calyces powder is a rich source of the vitamin B complex. These groups of vitamins are important in the metabolism of carbohydrates, proteins, and fats.

Table 2. Vitamin composition of dried Indian sorrel/roselle (Hibiscus sabdariffa L.) calyces.

\begin{tabular}{l|l|l} 
Vitamins & Concentration & RDA of ICMR \\
\hline vitamin C (ascorbic acid) & $12.20 \mathrm{mg} / 100 \mathrm{~g}$ & $40 \mathrm{mg} /$ day \\
\hline Vitamin B2(riboflavin) & $6.71 \mathrm{mg} / 100 \mathrm{~g}$ & $1.3-1.6 \mathrm{mg} / \mathrm{day}$ \\
\hline Vitamin B3 (niacin) & $1484.3 \mathrm{mg} / 100 \mathrm{~g}$ & $14-18 \mathrm{mg} /$ day \\
\hline Vitamin B5 (pantothenic acid) & $0.25 \mathrm{mg} / 100 \mathrm{~g}$ & \\
\hline Vitamin B6 (pyridoxin) & $53.78 \mathrm{mg} / 100 \mathrm{~g}$ & $2 \mathrm{mg} / \mathrm{day}$ \\
\hline Vitamin B9 (folic acid) & $51.80 \mathrm{mcg} / 100 \mathrm{~g}$ & $100 \mathrm{mcg} /$ day \\
\hline Vitamin B12 (cobalamine) & $9.13 \mathrm{mcg} / 100 \mathrm{~g}$ & $1 \mathrm{mcg} / \mathrm{day}$ \\
\hline Vitamin B1 (Thiamine) & ND & -
\end{tabular}

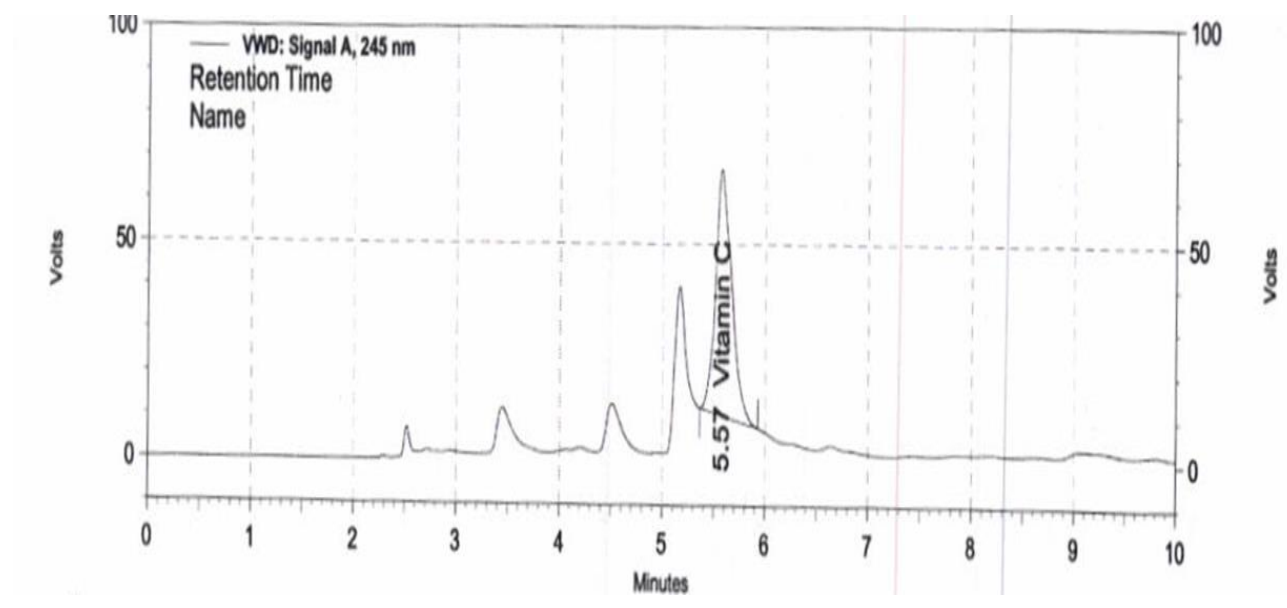

\begin{tabular}{rcccr|r} 
Pk\# & & Name & Retention Time & Area & Area Percent \\
\hline & 1 & Vitamin C & 5.57 & 10383528 & 100.00
\end{tabular}

Figure 1. HPLC chromatogram of vitamin C of dried Indian sorrel/roselle (Hibiscus sabdariffa L.) calyces.

\subsubsection{Mineral composition.}

, The mineral composition of the dried powdered calyces of Indian sorrel/roselle is given in Table 2. The results indicate that $\mathrm{Ca}, \mathrm{K}$, and $\mathrm{Mg}$ have the highest value, and $\mathrm{Fe}$ has the medium value, followed by $\mathrm{Na}, \mathrm{Zn}, \mathrm{Cu}$, and $\mathrm{Mn}$. Thus, the consumption of roselle calyces plays active roles in bones and teeth formation, muscle contraction, and many enzymatic activities. The recommended daily allowance of iron for adults is $28-38 \mathrm{mg}$ [27], and sufficient quantities of $\mathrm{Fe}(21.11 \pm 0.2 \mathrm{mg} / 100 \mathrm{~g})$ in hibiscus calyces are available for biochemical function as they are also rich in vitamin $\mathrm{C}$. $\mathrm{K}$ and $\mathrm{Na}$ are present in an equitable quantity, entailed to maintain the osmotic balance of the body fluid \& $\mathrm{pH}$ of the body [18], and $\mathrm{K}$ helps in the maintenance of the nervous system. However, there is variation in the mineral composition of the present study as compared to other studies done earlier, which may be attributed to the difference in the origin of soil [28]. 
Table 3. Mineral composition of dried Indian sorrel/roselle (Hibiscus sabdariffa L.) calyces.

\begin{tabular}{l|l} 
Test & Result $(\mathbf{m g} / \mathbf{1 0 0 g})$ \\
\hline Sodium & $7.74 \pm 0.08$ \\
\hline Potassium & $1263.47 \pm 0.5$ \\
\hline Calcium & $2105.78 \pm 0.2$ \\
\hline Iron & $21.11 \pm 0.2$ \\
\hline Magnesium & $280.12 \pm 0.3$ \\
\hline Manganese & $2.24 \pm 0.09$ \\
\hline Copper & $3.68 \pm 0.02$ \\
\hline Zinc & $5.73 \pm 0.01$
\end{tabular}

Results are expressed as mean \pm standard deviation of three measurements.

\subsubsection{Sugar profile.}

Figure 2 shows the distinct peak of sugars present in the dried calyces of Indian sorrel/roselle by HPLC chromatogram, and the relative amount of glucose, fructose, and sucrose are given in Table 2. The major sugar present in the powdered sample was glucose $(1.07 \% \mathrm{w} / \mathrm{w})$, followed by sucrose and fructose among them. These findings were not similar to the findings of Wong et al. [20], where the major sugar was glucose, followed by fructose and sucrose. Glucose serves as a source of energy that is utilized by the body for metabolic and biological function and is specifically significant for the brain, red blood cells, and muscle cells during workouts. The FDA has recommended that sugar intake should not be more than $10 \%$ of your daily calorie intake, but WHO has reduced it to $5 \%$ for the adult with normal BMI. Too much intake of sugar poses health risks like hyperlipidemia and cardiovascular diseases. The total sugar present in the dried calyces powder is $1.86 \% \mathrm{~W} / \mathrm{W}$; thus, Indian sorrel/roselle is characterized by very low sugar content.

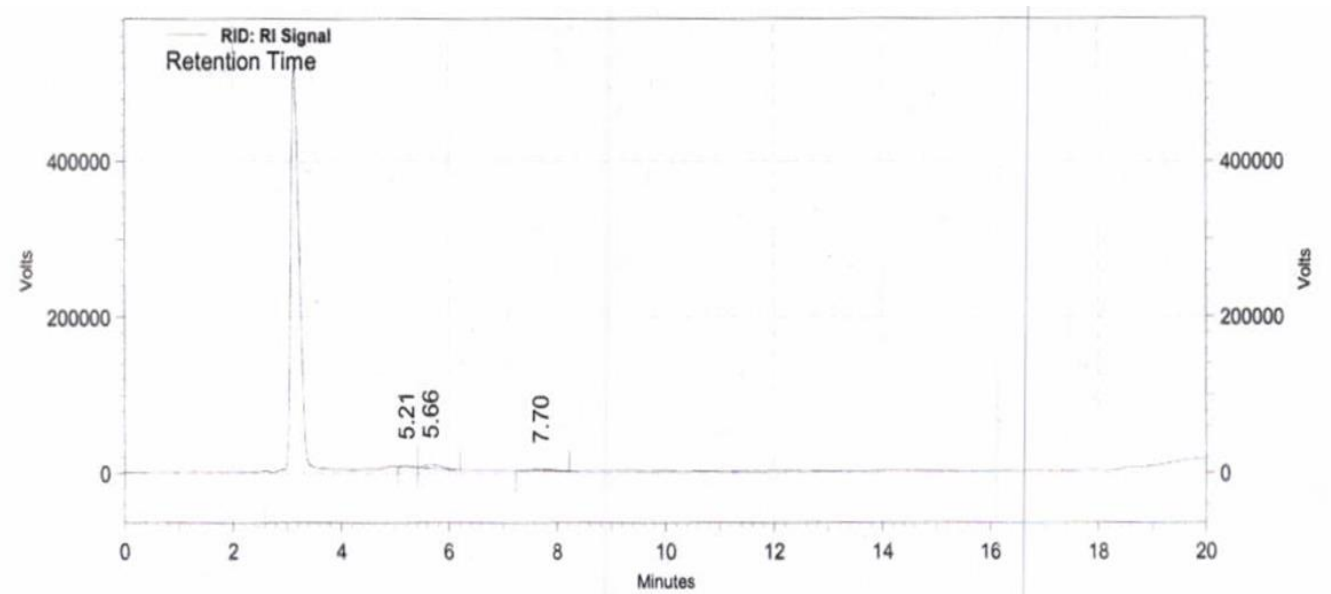

\begin{tabular}{ccccc} 
Peak Number & Name & Retention Time & Area & Area \% \\
\hline 1 & Fructose & 5.21 & 2200042 & 13.00 \\
2 & Dextrose & 5.66 & 10211273 & 60.35 \\
3 & Sucrose & 7.70 & 4509736 & 26.65
\end{tabular}

Figure 1. HPLC chromatogram of sugar profile of dried Indian sorrel/roselle (Hibiscus sabdariffa L.) calyces.

Table 4. Sugar composition of dried Indian sorrel/roselle (Hibiscus sabdariffa L.) calyces.

\begin{tabular}{l|c} 
Test & Result (\% dry weight basis) \\
\hline Glucose & 1.07 \\
\hline Fructose & 0.29 \\
\hline Sucrose & 0.5 \\
\hline Sum of sugars & 1.86
\end{tabular}




\subsubsection{Organic acid composition.}

The organic acid found in the Indian roselle is malic acid, oxalic acid, and Fumaric acid, as shown in Table 3. Malic acid was the most abundant acid present in the sample. Our findings were almost similar to the data in reference [29]. Malic acid reduces the symptoms of fibromyalgia.

Table 5. Organic acid composition of dried Indian sorrel/roselle (Hibiscus sabdariffa L.) calyces.

\begin{tabular}{l|l} 
Test & Result $(\mathbf{g} / \mathbf{1 0 0 g})$ \\
\hline Malic acid & 8.62 \\
\hline Oxalic acid & 2.01 \\
\hline Fumaric acid & 0.031
\end{tabular}

\subsection{Bioactive composition of dried Indian sorrel/roselle (Hibiscus sabdariffa L.) calyces.}

\subsubsection{Total phenolic content.}

As polyphenols are the important compounds that act as antioxidants and combat with various degenerative diseases, it is important to know the concentration of total polyphenols in the Indian species of roselle. Table 5 shows the total polyphenols found in the Indian sorrel/roselle was $38.58 \pm 1.06 \mathrm{mg} \mathrm{GAE} / \mathrm{g}$, which is within the range of the reported values $(32.893 \pm 0.319 \mathrm{gGAE} / \mathrm{Kg}, 41.72 \pm 2 \mathrm{mg} \mathrm{GAE} / \mathrm{g})[13,18]$ in spite of the fact there are variations in the reported value. These differences are basically due to the plant species, environmental factors, extracting procedure, or the solvent used for the extraction [30, 22].

\subsubsection{Total anthocyanins content.}

The anthocyanins are not merely wonderful antioxidants but are also splendid natural colorant due to it is bright red color that could be used in the food and pharmaceutical industries. Table 5 shows the total anthocyanins content in the dried powdered calyces that were found to be $635.86 \pm 1.02 \mathrm{mg} / 100 \mathrm{~g}$ on a dry weight basis. This value is in the range as reported in other studies in the literature $(0.76 \mathrm{~g} / 100 \mathrm{~g} ; 622.91 \mathrm{mg} / 100 \mathrm{~g})$ [31, 22]. Thus, we can ensure that dried roselle calyces are an excellent source of anthocyanins. Nevertheless, this value is higher as compared to the values $(4.08 \pm 0.02 \mathrm{mg} / \mathrm{g})$ reported by Jabeur et al. [26] in their study. This may be due to the differences in the plant species, methods of extraction, and the solvent used. Thus, the indigenous calyces are richer in anthocyanin pigments as compared to the calyces found in other countries.

Table 6. Bioactive composition of dried Indian sorrel/roselle (Hibiscus sabdariffa L.) calyces.

\begin{tabular}{l|l} 
Test & Results \\
\hline Total phenolic content as mg GAE/g & $38.58 \pm 1.06$ \\
\hline Total anthocyanin content (cyanidine-3-glucoside mg/100 gm) & $635.86 \pm 1.02$
\end{tabular}

Results are expressed as a mean \pm standard deviation of three measurements.

3.3.3. Identification of anthocyanins by thin-layer chromatography (TLC).

Figure 3 showing the TLC plate with two main anthocyanins present in the Indian sorrel/roselle. The Rf values were confirmed by comparing the values from the literature. The color of the two pigments identified as D-3-sambubioside and cyanidin-3-sambubioside was mauve and pink, respectively. The Rf values were $0.25 \& 0.33$, which was almost the same as reported by Du \& Francis (1973) [32]. 


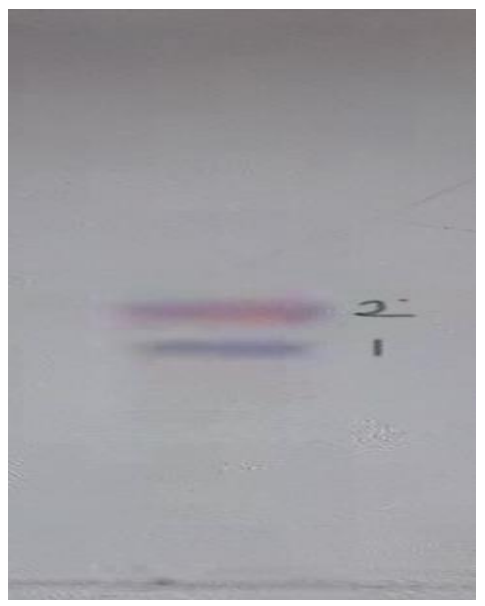

Figure 3. TLC plate showing the separation of two major anthocyanins in the Indian sorrel/roselle calyces powder. Chromatogram 1: D-3-sambubioside Chromatogram 2: Cyanidine-3-sambubioside.

Table 7 showing the Visible maxima and Rf value of the major anthocyanins (D-3sambubioside and cyanidin-3-sambubioside) present in the Indian calyces powder.

Table 7. Major anthocyanins found in dried Indian sorrel/roselle (Hibiscus sabdariffa L.) calyces.

\begin{tabular}{l|l|c|c|c} 
Peak & Identification & Visible maxima & Rf x 100 & Reference \\
\hline a & Delphinidine-3-sambubioside & 543 & 25 & Du and Francis (1973) \\
\hline b & Cyanidin-3-sambubioside & 528 & 33 &,
\end{tabular}

\section{Conclusions}

Roselle being a rich source of macro and micronutrients, have enormous potential for livelihood enhancement and socio-economic development by making a variety of value-added food products. The study illustrates a preliminary attempt to characterize the nutritional and phytochemical components of the locally produced roselle (Hibiscus sabdariffa L.). Our study substantiates its applicability as a functional food or functional food ingredients. It also has the immense potential to be used in the therapeutic treatment of various diseases in developing countries like India, where the maximum population largely relies on traditional medicine. Further, in the present situation, when the entire world is affected by the COVID-19 pandemic, this indigenous plant has the potency to be anticipated as an effective drug being rich in phytochemical agents. In this regard, there is an urgent need to study the antioxidant properties of the indigenous variety of roselle (Hibiscus sabdariffa L.) as well, the clinical trials are also recommended.

\section{Funding}

This research received no external funding.

\section{Acknowledgments}

This research has no acknowledgment.

\section{Conflicts of Interest}

The authors declare no conflict of interest. 


\section{References}

1. Riaz, G.; Chopra, R. A review on phytochemistry and therapeutic uses of Hibiscus sabdariffa L. Biomedicine \& Pharmacotherapy 2018, 102, 575-586, https://doi.org/10.1016/j.biopha.2018.03.023.

2. Izquierdo-Vega,J.A.; Arteaga-Badillo, D.A.; Sanchez-Gutierrez, M.; Morales-Gonzalez, J.A.; VargasMendoza, N.; Gomez-Aldapa, C.A.; Castro-Rosas, J.; Delgado-Olivares, L.; Madrigal-Bujaidar, Eduardo.; Madrigal-santillan, E. organic Acids From Roselle (Hibiscus sabdariffa L.)-A brief Review of its Pharmacological Effects. Biomedicines 2020, 8, 100, http://doi.org/10.3390/biomedicines8050100.

3. Cissé, M.; Bohuon, P.; Sambe, F.; Kane, C.; Sakho, M.; Dornier, M. Aqueous extraction of anthocyanins from Hibiscus sabdariffa: Experimental kinetics and modeling. Journal of Food Engineering 2012, 109, 1621, https://doi.org/10.1016/j.jfoodeng.2011.10.012.

4. Borrás-Linares, I.; Fernández-Arroyo, S.; Arráez-Roman, D.; Palmeros-Suárez, P.A.; Del Val-Díaz, R.; Andrade-Gonzáles, I.; Fernández-Gutiérrez, A.; Gómez-Leyva, J.F.; Segura-Carretero, A. Characterization of phenolic compounds, anthocyanidin, antioxidant and antimicrobial activity of 25 varieties of Mexican Roselle (Hibiscus sabdariffa). Industrial Crops and Products 2015, 69, 385-394, http://doi.org/10.1016/j.indcrop.2015.02.053.

5. Pozos, G.; Ruiz, M.; Zamora-Natera, J.; Moya, C.; Ramírez, L.; Reynoso Silva, M.; Macías, R.; Garcia, P.; González-Cruz, R.; Pérez, E.; Vargas-Radillo, J. Antioxidant Capacity and Antigenotoxic Effect of Hibiscus sabdariffa L. Extracts Obtained with Ultrasound-Assisted Extraction Process. Applied Sciences 2020, 10, 560, https://doi.org/10.3390/app10020560.

6. Ansari Dogaheh, M.; Eslaminejad, T. An Overview of the Roselle Plant with Particular Reference to Its Cultivation, Diseases and Usages. European Journal of Medicinal Plants 2013, 3, 135-145, https://doi.org/10.9734/EJMP/2013/1889.

7. Ismail, A.; Ikram, E.H.K.; \& Nazril, H.S.M. Roselle (Hibiscus sabdariffa L.) seeds nutritional composition protein quality and health benefits. Food 2008, 2, 1-16.

8. Biswa, D.; Singo, T.M. Effect of roselle extracts on the selected quality characteristics of ice cream. International Journal of Food Properties 2019, 22, 42-53, http://doi.org/10.1080/10942912.2019.1567535.

9. Wu, C.-H.; Huang, C.-C.; Hung, C.-H.; Yao, F.-Y.; Wang, C.-J.; Chang, Y.-C. Delphinidin-rich extracts of Hibiscus sabdariffa L. trigger mitochondria-derived autophagy and necrosis through reactive oxygen species in human breast cancer cells. Journal of Functional Foods 2016, 25, 279-290, https://doi.org/10.1016/j.jff.2016.05.018.

10. Mazumder, P.B.; Laskar, Y.B. Insight into molecularevidence supporting the remarkable chemotherapeutic potential of Hibiscus sabdariffa 1. Biomedicine \& Pharmacotherapy 2020, 127, 1-10, http://doi.org/10.1016/j.biopha.2020.110153.

11. Da-Costa-Rocha; Bonnlaender, B.; Sievers, H.; Pischel, I.; Heinrich, M. Hibiscus sabdariffa L.-a phytochemical and pharmacological review. Food chemistry 2014, 165, 424-443, https://doi.org/10.1016/j.foodchem.2014.05.002.

12. Menzi, A.; Mhadhbi, L.; Khazri, A.; Sellami. B.; Dellali, M., Mahmoudi, E.; Beyrem, H. Pesticide Biochemistry and Physiology 2020, 165, 104463, http://doi.org/10.1016/j.pestbp.2019.09.007.

13. Cisse, M.; Dornier, M.; Sakho, M.; Ndiaye, A.; Reynes, M.; Sock, O. Le bissap (Hibiscus sabdariffa L.) : composition et principales utilisations. Fruits 2009, 64, 179-193, https://doi.org/10.1051/fruits/2009013.

14. Maganha, E.G.; Halmenschlager, R.d.C.; Rosa, R.M.; Henriques, J.A.P.; Ramos, A.L.L.d.P.; Saffi, J. Pharmacological evidences for the extracts and secondary metabolites from plants of the genus Hibiscus. Food Chemistry 2010, 118, 1-10, https://doi.org/10.1016/j.foodchem.2009.04.005.

15. Ali, M.B.; Salih, W.M.; Mohamed, A.H.; Homeida, A.M. Investigation of the antispasmodic potential of Hibiscus sabdariffa calyces. Journal of Ethnopharmacology 1991, 31, 249-257, https://doi.org/10.1016/0378-8741(91)90009-3.

16. Adams, S.; Senthil Kumar, T.; Muthuraman, G.; Majeed, A. Mineral Elements and Their ICP-MS Validation in Crepidium acuminatum (D.Don) Szlach.- An Ashtavarga Plant. Asian Journal of Biochemical and Pharmaceutical Research 2017, 7, 38-46, https://doi.org/10.24214/AJBPR/7/4/3846.

17. Ewaidah, E.H. Nutritive composition of Al-Nokel grape fragments and the potentiality of making evaporator-concentrate. Food Chemistry 1993, 46, 243-252, https://doi.org/10.1016/0308-8146(93)90114U.

18. Dias, M.I.; Barros, L.; Dueñas, M.; Pereira, E.; Carvalho, A.M.; Alves, R.C.; Oliveira, M.B.P.P.; SantosBuelga, C.; Ferreira, I.C.F.R. Chemical composition of wild and commercial Achillea millefolium L. and bioactivity of the methanolic extract, infusion and decoction. Food Chemistry 2013, 141, 4152-4160, https://doi.org/10.1016/j.foodchem.2013.07.018.

19. Kalla, M.L.M.; Jong, E.N.; Kayem, J.G.; Sreekumar, M.M.; Nisha, P. Effect of re-extraction parameters and drying temperature on the antioxidant properties and dietary fiber of Red sorrel (Hibiscus sabdariffa L.) calyces residues. Industrial Crops and Products 2015, 74, 680-688, https://doi.org/10.1016/j.indcrop.2015.05.028. 
20. Lee, J.; Durst, R.; Wrolstad, R. Determination of total monomeric anthocyanin pigment content of fruit juices, beverages, natural colorants, and wines by the $\mathrm{pH}$ differential method: Collaborative Study. Journal of AOAC International 2005, 88, 1269-1278.

21. Wagner, H.; Bladt, S. Drug containing pigments. In: Book Plant Drug Analysis, A thin Layer Chromatography Atlas. $2^{\text {nd }}$ ed.; Springer-Verlag Berlin Heidelberg New York, 1996; pp. 281-288.

22. Puro, K.-u.; Aochen, C.; Ghatak, S.; Das, S.; Sanjukta, R.; Mahapatra, K.; Jha, A.K. Studies on the therapeutic properties of Roselle (Hibiscus sabdariffa) calyx: A popular ingredient in the cuisine of North East India. International Journal of Food Science and Nutrition 2017, 2, 01-06.

23. Sáyago-Ayerdi, S.G.; Arranz, S.; Serrano, J.; Goñi, I. Dietary Fiber Content and Associated Antioxidant Compounds in Roselle Flower (Hibiscus sabdariffa L.) Beverage. J Agric Food Chem 2007, 55, 7886-7890, https://doi.org/10.1021/jf070485b.

24. Wong, P.-K.; Yusof, S.; Ghazali, H.M.; Che Man, Y.B. Optimization of hot water extraction of roselle juice using response surface methodology: a comparative study with other extraction methods. Journal of the Science of Food and Agriculture 2003, 83, 1273-1278, https://doi.org/10.1002/jsfa.1416.

25. Abou-Arab, A.; Ferial, M.; Abu-salem; \& Esmat, A.A.-A. Physico-chemical properties of natural pigments (anthocyanins) extracted from roselle calyces (Hibiscus sabdariffa). Journal of American Science 2011, 7, 445-456.

26. Luvonga, W.A.; Nijorge, M.S.; Makokha, A.; Ngunjiri, P.W. Chemical charecterization of Hibiscus sabdariffa (roselle) calyces and evaluation of its functional potential in the food industry. Proceedings of JKUAT Scientific and Industrial Conference. Kenya. 2010, 631-638.

27. Chutani, A.H. Nutrition and dietary habits. Nutritional Biochemistry 2008.

28. Carvajal-Zarrabal,O.; Barradas-Dermitz, D.M.; Orta-Flores, Z.; Hayward-Jones, P.M.; Nolasco-Hipolito, C.; Aguilar-Uscanga, M.G.; Meranda-Medina, A.; Bujang, K.B. Hibiscus sabdariffa L., roselle calyx from ethanobotany to pharmacology, Journal of Experimental Pharmacology 2012, 4, 25-39, https://doi.org/10.2147/JEP.S27974.

29. Jabeur, I.; Pereira, E.; Barros, L.; Calhelha, R.C.; Sokovic, M.; Oliveira, M.B.P.P.; Ferreira, I.C.F.R. Hibiscus sabdariffa L. as a source of nutrients, bioactive compounds and colouring agents. Food Research International 2017, 100, 717-723, https://doi.org/10.1016/j.foodres.2017.07.073.

30. Liu, J.-Y.; Chen, C.-C.; Wang, W.-H.; Hsu, J.-D.; Yang, M.-Y.; Wang, C.-J. The protective effects of Hibiscus sabdariffa extract on CCl4-induced liver fibrosis in rats. Food and Chemical Toxicology 2006, 44, 336-343, https://doi.org/10.1016/j.fct.2005.08.003.

31. Sinela, A.; Dornier, M. Anthocyanins degradation during storage of Hibiscus sabdariffa extract and evolution of its degradation products. Food Chemistry 2017, 214, 234-241, https://doi.org/10.1016/j.foodchem.2016.07.071.

32. Du, C.T.; Francis, F.J. Anthocyanin of Roselle (Hibiscus sabdariffa L.). Journal of food science 1973, 38, 810-812, https://doi.org/10.1111/j.1365-2621.1973.tb02081.x. 